\title{
EFFECTS OF CLEOME ARABICA AQUEOUS EXTRACTS IN WISTAR RAT'S BEHAVIOR, BIOCHEMISTRY PARAMETERS AND ACTH HORMONE
}

\author{
Nour El Imene Boublata ${ }^{1 *}$, Wafa Habbachi ${ }^{2}$, Sarra Habbachi ${ }^{2}$, Fatma Zohra Saadane ${ }^{2}$, \\ Saliha Benhissen ${ }^{2,3}$, Abdelkrim Tahraoui ${ }^{2}$ \\ ${ }^{1}$ Laboratory of Environmental Biosurveillance. Department of Biology, Faculty of Sciences, \\ University Badji Mokhtar Annaba 23000, Algeria \\ ${ }^{2}$ Laboratory of Applied Neuroendocrinology. Department of Biology, Faculty of Sciences, \\ University Badji Mokhtar Annaba 23000, Algeria \\ ${ }^{3}$ Department of Biology, Faculty of Sciences, University Med Boudiaf, M'Sila 28000, Algeria
}

\begin{abstract}
Cleome arabica is a spontaneous plant in arid areas, toxic and has hallucinogenic effects. Despite its dangers, this plant is used till now in folk medicine. In this work we seek to evaluate the aqueous extract effect of this plant on the Wistar rat anxiety behaviour and their effects in stress physiology (effect in glycemia, ACTH hormone, creatinine, cholesterol...etc.). To do there, the treatment is done by gavage of $1 \mathrm{ml} C$. arabica $(0.17 \mu \mathrm{g} / \mathrm{l})$ for 7 successive days.

Different behavioral tests (raised cross maze, open field and forced swimming) show that the plant extract had a significant impact on the anxiety level (treated rats exhibit anxious behavior). This extract has a significant influence on biochemical parameters (glycemia, cholesterol, triglycerides, urea, and creatinine) and on the ACTH hormone (Adreno CorticoTropic Hormone).
\end{abstract}

Keywords: Anxious behavior, Cleome arabica, Saharan plant, Wistar rat.

\section{INTRODUCTION}

Plants play an essential role in the health care needs for the treatment of diseases and to improve the immunological response against much pathology Sharma et al., (2011). Plant extracts are potentially curative. Some of these extracts can boost the humoral and cell mediated immunity against viruses, bacteria, fungi, protozoa and cancer Malwal and Sarin, 2011; Párraga et al., 2011; Choudhury and Sinha, 2011). The use of herbal medicine is a common practice in many countries, particularly in Asia (Chacko, 2003) and Africa (Shapiro and Gong,2002). Herbal medicines are promising choice over synthetic drugs, Cleome droserifolia medicinal herb belongs to Family Cleomaceae. The dried herb of $C$. droserifolia, locally named in Egypt Samwah and used as hypoglycemic plant by herbalists. (Abdelfattah et al., 2019).

The management of these problems has prompted researchers to move towards biological control in its various forms. New methods, as well as new products, are constantly being sought. In addition, to contribute to sustainable environmental management, the introduction of new alternatives for pest control is further encouraged (Louat, 2013). 
The Algerian Sahara has an exceptional floristic biodiversity, consisting of more than 500 species, of which there are 162 endemic species in the northern Sahara alone and to which is added a tradition of traditional pharmacopeia (Ozenda,1991). Several species are known for their remarkable therapeutic properties (Quezel, 1978).

Spontaneous plants in arid area are considered as phytogenetic resources of agronomic, economic, ecological and strategic interest (UNESCO, 1960). Plant extracts have been used as insecticides by humans before Romans time, this practice continues to exist with many plants species known for their insecticidal properties (Balandrin et al., 1985; Isman, 2002). Plant products can be degraded more rapidly in the environment than synthetic compounds, and some may have increased specificity that may favor beneficial insects for the plant (Desneux et al., 2007).

In this work we are trying to test the effect of the aqueous extract of the Algerian Sahara plant Cleome arabica (Capparidaceae) on the Wistar rat. The plant C. arabica is a green, briefly hairy, glandular, viscous, and annual herb, 30-50 cm high, with erect and branched stems, trifoliolate leaves, elongated silica fruit opening through 2 valves, seeds covered with hairs as long as the diameter of the seed (Ozenda, 1991).

These leaves have 3 oval and alternate leaflets with yellow flowers in their axils edged with purple strands. These perianths have four petals, four green sepals and six stamens. It also has fruits in the form of oblong capsules, about 1 to $2 \mathrm{~cm}$ long, which appear before the petals wilt and resemble beans and bear very short-haired seeds (Baba, 2000).

Because their big use in medicine folk and in pests control, the objective of this study is to determine dangers, efficacy and the neurobehavioral consequences of the administration of $C$. arabica aqueous extract (common name: natten, a spontaneous plant of the Algerian Sahara) on Wistar rat (as research model).

\section{MATERIALS AND METHODS}

\subsection{Animal:}

We used the adult rats "Rattus rattus" of the Wistar strain, from the Pasteur Institute of Algiers (Algeria), to carry out the various experiments. The rats were raised in plastic cages lined with sawdust and fitted with steel lids and water-filled bottles. The rats were fed with sticks of corn, barley, milk and vitamin supplements. These animals have been acclimatised to the laboratory conditions (temperature $25 \pm 2^{\circ} \mathrm{C}$ and humidity $70-80 \%$ and photoperiod $12: 12 \mathrm{~h}$ ).

\subsection{Cleome arabica (Capparidaceae) :}

It is a plant with a foul odour, toxic and hallucinogenic effects (Gubb, 1913; Ozenda, 1991). The plant is used in traditional medicine as a diuretic and against rheumatism; it is also a therapeutic and anti-bacterial plant (Ladhari et al., 2013). The effect of this species has also been proven against different orders of insects (Ozenda, 1991; Doumandji-Mitiche and Doumandji, 1993; N'Guessan et al., 2009; Koïta et al., 2012). For the present study, the plant was collected in the Bousaada region

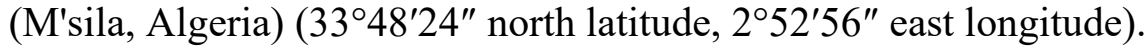

\subsubsection{Preparation of the aqueous extract of $C$. arabica:}

For the extract, we put $170 \mathrm{~g}$ of powdered leaves in 11 of distilled water and boil for 30 minutes on a hot plate at $180^{\circ} \mathrm{C}$. The resulting mixture is filtered through filter paper and $750 \mathrm{ml}$ of the filtrate $(1$ $\mathrm{g} / \mathrm{l}$ stock solution) is recovered. 


\subsection{Treatments:}

Forty rats were separated into two groups, a control group (20 individuals: 10 males and 10 females) and a treatment group (20 individuals: 10 males and 10 females). Who will undergo the intoxication, by gavage, of $1 \mathrm{ml}$ of $C$. arabica $(0.17 \mu \mathrm{g} / \mathrm{ml})$ for 7 successive days.

\subsection{Rat's Behaviors in different anxiety-provoking situations:}

We tested the different rats groups using experimental devices recognized by the scientific society whose most used are the plus maze (EPM) (Rodgers and Dalvi, 1997; VanGaalen and Steckler, 2000; Karl et al., 2003; Elizalde et al., 2008), the open field (OP) (Crawley, 1999; Palanza, 2001; Karl et al., 2003; Prut and Belzung, 2003; Elizalde et al., 2008) and the forced swimming test or Porsolt test (FST) (Porsolt et al., 1977; Karl et al., 2003; Elizalde et al., 2008).

\subsection{Effect on certain biochemical parameters:}

Blood is collected from control adults and C. arabica's adults. The separated plasma is frozen and stored immediately at $\left(-20^{\circ} \mathrm{C}\right)$. ACTH plasmas were measured by radioimmunoassay (Raff et al., 2004). We also performed a blood glucose, cholesterol, triglyceride, urea and creatinine.

\subsection{Data Analysis:}

The various study data were analyzed by descriptive and comparative methods (variances analysis) on XLStat 2009 software. The multivariate analysis (ANOVA) with SPSS Statistics 22.0 enabled us to test treatment and sex effects on the rat behaviors tested and biochemical parameters.

\section{RESULTS AND DISCUSSIONS}

\subsection{Behaviors of rats in different anxiety-provoking situations:}

\subsubsection{Plus maze test:}

This test is used to evaluate anxiety about vacuum (Kousteff, 2011). The rat is anxious and naturally takes refuge in the closed arms which offer him greater security and will hesitate to explore with open arms (Rodgers and Dalvi, 1997; VanGaalen and Steckler, 2000; Karl et al., 2003; Elizalde et al., 2007; Kousteff, 2011). Our results show that there are highly significant differences and highly significant differences between time spent in closed and/or open arms in control and treated rats for both sexes (Tab. 1). A short time spent in open arms is considered an index of anxiety (Pellow et al., 1985; Lister, 1987; Onaivi et al., 1990); this index averages 55-58 seconds for males and 60-117 seconds for females. However, we recorded that the number of entries into the open arms decreased in treated males and females compared to controls; the decrease in venturing into the open arms in the raised cross maze is typically interpreted as an increase in anxiety (Elliott et al., 2004).

Table 1. Effect of the plant C. arabica on the behavior of rats (in plus maze)

\begin{tabular}{|c|c|c|c|c|}
\hline$N=10$ & $\begin{array}{c}\text { Time spent in closed } \\
\text { arms }\end{array}$ & $\begin{array}{c}\text { Time spent in open } \\
\text { arms }\end{array}$ & $\begin{array}{c}\text { Number of closed } \\
\text { arms }\end{array}$ & $\begin{array}{c}\text { Number of open } \\
\text { arms }\end{array}$ \\
\hline${ }^{1} \boldsymbol{C}$ & $235.60 \pm 0,40$ & $58 \pm 0.64$ & $5.75 \pm 0,48$ & $2.50 \pm 0.65$ \\
\hline$\widehat{C} \boldsymbol{C} . \boldsymbol{a}$ & $240.40 \pm 0.58$ & $55.60 \pm 0.10$ & $1.25 \pm 0.25$ & $1.25 \pm 0.25$ \\
\hline$F_{o b s}$ & 46.70 & 6.14 & 69.43 & 3.26 \\
\hline $\boldsymbol{P}$ & $0.002 * *$ & 0.07 & $0.0002 * * *$ & 0.120 \\
\hline${ }_{q} \boldsymbol{C}$ & $175.78 \pm 2,30$ & $117.80 \pm 1,74$ & $6.50 \pm 0.29$ & $5.50 \pm 0.65$ \\
\hline C. $\boldsymbol{C}$ & $238.07 \pm 1.45$ & $60.00 \pm 3.00$ & $2.50 \pm 0.65$ & $3.00 \pm 0.40$ \\
\hline$F_{\text {obs }}$ & 438.46 & 332.79 & 32.00 & 10.70 \\
\hline$P$ & $0.000 * * *$ & $0.0003 * * *$ & $0.001 * *$ & $0.02 *$ \\
\hline
\end{tabular}

[C: Control; C.a: C. arabica] [* significant*; ** highly significant; *** very highly significant] 


\subsubsection{Open Field Test:}

This test evaluates an animal's response to a new and spacious environment (Kousteff, 2011). It creates a conflict situation between the animal's natural tendency to explore this new environment and its aversion to open spaces (Kousteff, 2011). As a result, normal rats tend to spend more time in corners and periphery of open field (the open field's center is considered the most anxietyprovoking area) (Crawley, 1999; Palanza, 2001; Karl et al., 2003; Prut and Belzung, 2003; Elizalde et al., 2008).The results reported in Table 2 show that control and treated rats prefer to remain in the periphery of the open field. The table also shows that the number of straightening, time spent in corners and downtime decreased in males when treating rats with $C$. arabica; these three parameters were relatively higher in females than in males (Tab. 2). This test consists of measuring locomotors activity (Tayaa, 2014). C. arabica extract has a significant effect on this activity. Some products cause acute locomotor hypoactivity such as organophosphate pesticides (Tayaa, 2014); disturbances in the functioning of the GABAergic system involve anxiety disorders (Mohler, 2006; Domschke and Zwanzger, 2008).

Table 2. Effect of the plant C. arabica on the behavior of rats (in open filed)

\begin{tabular}{|c|c|c|c|c|c|}
\hline$N=10$ & $\begin{array}{c}\text { Time spent in } \\
\text { the central } \\
\text { area }\end{array}$ & $\begin{array}{c}\text { Time } \\
\text { spent in the } \\
\text { peripheral area }\end{array}$ & $\begin{array}{c}\text { Time } \\
\text { spent in the } \\
\text { corners }\end{array}$ & $\begin{array}{l}\text { Number of } \\
\text { adjustments }\end{array}$ & $\begin{array}{c}\text { Time of } \\
\text { immobility }\end{array}$ \\
\hline $\bar{C}$ & $0.33 \pm 0.08$ & $299.70 \pm 0.09$ & $180.05 \pm 1.25$ & $15.50 \pm 0.65$ & $117.05 \pm 0.15$ \\
\hline$\widehat{C} \cdot \boldsymbol{a}$ & $0.25 \pm 0.05$ & $295.53 \pm 0.99$ & $173.05 \pm 4.15$ & $10.75 \pm 0.48$ & $122.53 \pm 3.51$ \\
\hline$F_{o b s}$ & 0.69 & 24.86 & 2.61 & 34.94 & 1.47 \\
\hline$p$ & 0.44 & $0.004 * *$ & 0.25 & $0.001 * *$ & 0.31 \\
\hline${ }_{+} \boldsymbol{C}$ & $0.33 \pm 0.08$ & $299.30 \pm 0.13$ & $181.07 \pm 2.70$ & $13.50 \pm 0.65$ & $119.60 \pm 1.53$ \\
\hline$q \boldsymbol{C} . \boldsymbol{a}$ & $0.25 \pm 0.05$ & $298.25 \pm 0,35$ & $185.23 \pm 2,77$ & $22 \pm 2.08$ & $174.13 \pm 2.09$ \\
\hline$F_{o b s}$ & 0.57 & 7.83 & 1.16 & 19.98 & 442.69 \\
\hline$p$ & 0.48 & $0.03 *$ & 0.34 & $0.007 * *$ & $0.000 * * *$ \\
\hline
\end{tabular}

[C: Control; C.a: C. arabica] [* significant*; ** highly significant; *** very highly significant]

\subsubsection{Forced swim test:}

This test is to put the rat in a dangerous situation where he must struggle to survive, but without flees' possibility. The forced swimming test or the antidepressant efficacy test represents an aversive and stressful situation where the rat can't escape and produces immobility and despair behavior (Porsolt et al., 1978; Kirby and Lucki, 1997). In animals, immobility is interpreted as a lack of will to survive and considered as a depression sign (Porsolt et al., 1977, Petit Demouliere et al., 2005). The results show that the aqueous extract has a highly significant influence on swimming time in treated females (Tab. 3). We recorded that the time of climbing and/or immobility are less important in these treated individuals (Tab. 3). This result confirms the increase in signs of depression due to the use of $C$. arabica extract. 
Current Trends in Natural Sciences

Vol. 9, Issue 18, pp. 202-209, 2020

https://doi.org/10.47068/ctns.2020.v9i18.028

Current Trends in Natural Sciences (on-line)

Table 3. Effect of the plant C. arabica on depressive state

\begin{tabular}{|c|c|c|c|}
\hline$N=10$ & Swimming time & Climbing time & Time of immobility \\
\hline $\bar{\delta} \boldsymbol{C}$ & $126.33 \pm 2.03$ & $2.28 \pm 0,07$ & $61.70 \pm 0.61$ \\
\hline${ }^{\lambda} \boldsymbol{C} . \boldsymbol{a}$ & $123.17 \pm 1.60$ & $1.75 \pm 0.05$ & $62.80 \pm 0.50$ \\
\hline$F_{o b s}$ & 1.50 & 33.92 & 1.59 \\
\hline$p$ & 0.29 & $0.001 * *$ & 0.30 \\
\hline$q \boldsymbol{C}$ & $126.53 \pm 0.84$ & $2.48 \pm 0.14$ & $117.17 \pm 1.40$ \\
\hline$q \boldsymbol{C . a}$ & $237.58 \pm 0.57$ & $1.68 \pm 0.05$ & $63.07 \pm 1.07$ \\
\hline$F_{o b s}$ & 11939.11 & 2793 & 945.49 \\
\hline$p$ & $0.000 * * *$ & $0.002 * *$ & $0.000 * * *$ \\
\hline
\end{tabular}

[C: Control; C.a: C. arabica] [* significant*; ** highly significant; *** very highly significant]

\subsection{Effect of the $C$. arabica plant on biochemical parameters and the hormone ACTH :}

Our results show that blood sugar levels are lower in treated individuals. Helal et al., (2002) were work the mechanism of the hypoglycemic effect of an aqueous extract from Cleome droserifolia (SAMWA) and they studied in a group of glucose intolerant senile rats and they compared it with normal senile control rats. The results of this study show that the plant extract significantly suppressed the rise in blood glucose concentration. The hypoglycemic effect of the plant extract without increasing insulin secretion was explained by potentiation of peripheral and hepatic insulin sensitivity, and by diminishing intestinal glucose absorption, which was evident by blunting plasma glucose levels throughout the oral glucose challenge. This was accompanied by a significant decrease of liver glycogen content and a highly significant increase in leptin concentration which may suggest an anti-obesity role for the plant extracts. Plant extracts also decreased serum urea nitrogen. No changes on liver or heart function were observed. C. droserifolia extracts might prove to have a promising therapeutic value in the treatment of diabetes mellitus. Besides its suppression to hepatic glucose output, SAMWA beneficial therapeutic finding in favor of the plant as a replacement for insulin which is the most important drug that brings bout this effect (Helal et al., 2002). The hypoglycemic effect of the studied plant extract may be attributed to the presence of certain constituents such as flavonoids, glycosides, glycans, alkaloids, saponins and glycoproteins, these compounds were shown to have insulin mimetic effects and reduce blood glucose levels (Ahmed et al., 2010).

Cholesterol levels also decrease after treatment with $C$. arabica. This increased cholesterol level was found to activate these cells and lead to enhanced production of reactive oxygen species (ROS) (Kamesh and Sumathi, 2012). Samout et al (2015) showed a significant increase in the total cholesterol, LDL-chol and triglycerides levels, and a significant de- crease in HDL-chol in the hypercholester- olemic rats compared to controls. After three months of treatment with C.arabica leaf extract, these biomarkers were found to revert to almost control values.

C. arabica induces a significant decrease in Triglycerides, Urea and Creatinine levels. In Samout et al study (2015), it was found that an increase in total plasma TG, SGOT, SGPT, LDH, PAL, urea and creatinine occurred with a decrease in HDL-chol and uric acid value.

A similar study by Samout et al (2015) Our results are similar to this study which shows that C.arabica acts on the rate of urea and creatinine which decrease after treatment with the plant for 3 months. This study also shows that the plant acts on antioxidant enzymes at the level of liver, heart and kidney tissues and those by decreasing the quantity of GPX, SOD and CAT at the level of these organs. 


\section{Current Trends in Natural Sciences}

Vol. 9, Issue 18, pp. 202-209, 2020

https://doi.org/10.47068/ctns.2020.v9i18.028

Current Trends in Natural Sciences (on-line)

ISSN: 2284-953X

Current Trends in Natural Sciences (CD-Rom)

ISSN: 2284-9521

ISSN-L: 2284-9521

ISSN-L: 2284-9521

We recorded a significant decrease in the level of this hormone in males and females treated with the aqueous extract of this plant, which is consistent with the results of Oliver et al., (1994) when using G. biloba extract decreased the concentration of nor-epinephrine, adrenocorticotrophic hormones, epinephrine and corticosterone and those of Bekhakheche et al., (2018) when they used Citrullus colocynthis on females of the Wistar rat. As for biochemical parameters, highly significant effects were recorded in males treated with the aqueous extract of C. arabica compared to controls. The plant acts mainly on the biochemical profile of males than females. Many studies indicate the effects of plants on the biochemical and hematological profile of rats such as the studies of Choudhury and Sinha in 2011 and Joel Enoch et al in 2014 when using the aqueous extract of Murraya koenigii which acts significantly on rat blood cells, hormonal secretions and blood sugar levels. Our plant $C$. arabica, has proven its effectiveness by inducing a cholesterol-lowering effect in Wistar rats (Samout et al., 2015).

Table 4. Effect of the C. arabica plant on biochemical parameters and the hormone ACTH

\begin{tabular}{|c|c|c|c|c|c|c|}
\hline$N=10$ & $\begin{array}{c}\text { Glycemia } \\
(\mathrm{g} / \mathrm{l})\end{array}$ & $\begin{array}{c}\text { Cholesterol } \\
(\mathrm{g} / \mathrm{l})\end{array}$ & $\begin{array}{c}\text { Triglyceride } \\
(\mathrm{g} / \mathrm{l})\end{array}$ & $\begin{array}{l}\text { Urea } \\
(\mathrm{g} / \mathrm{l})\end{array}$ & $\begin{array}{c}\text { Creatinine } \\
(\mathrm{mg} / \mathrm{l})\end{array}$ & $\begin{array}{l}A C T H \\
(p g / m l)\end{array}$ \\
\hline $\bar{C}$ & $0.59 \pm 0.03$ & $0.91 \pm 0.05$ & $0.89 \pm 0.03$ & $0.44 \pm 0.02$ & $9.47 \pm 0.32$ & $20.69 \pm 0.88$ \\
\hline त.a & $0.65 \pm 0.06$ & $0.74 \pm 0.03$ & $0.56 \pm 0.04$ & $0.30 \pm 0.01$ & $7.08 \pm 0.63$ & $14.35 \pm 1.95$ \\
\hline$F_{o b s}$ & 1.00 & 7.37 & 44.08 & 50.70 & 11.34 & 8.78 \\
\hline$P$ & 0.36 & $0.03 *$ & $0.001 * *$ & $0.0003 * * *$ & $0.01 *$ & $0.02 *$ \\
\hline$q \boldsymbol{C}$ & $0.88 \pm 0.02$ & $0.65 \pm 0,01$ & $0.90 \pm 0,07$ & $0.41 \pm 0,01$ & $3.14 \pm 2,32$ & $8.12 \pm 2.60$ \\
\hline${ }_{+} \boldsymbol{C} . \boldsymbol{a}$ & $0.56 \pm 0.08$ & $0.54 \pm 0,07$ & $0.83 \pm 0,04$ & $0.44 \pm 0,01$ & $8.96 \pm 0,22$ & $4.94 \pm 1.44$ \\
\hline$F_{o b s}$ & 22.64 & 2.70 & 0.88 & 2.94 & 6.26 & 1.15 \\
\hline$P$ & $0.005 * *$ & 1.15 & 0.38 & 0.14 & $0.04 *$ & 0.32 \\
\hline
\end{tabular}

[C: Control; C.a: C. arabica] [* significant $* * *$ highly significant; *** very highly significant]

\section{CONCLUSIONS}

This study indicates that the aqueous extract of $C$. arabica has an antioxidant effect and can be used as an anti-diabetic treatment. The results of this work show that the plant acts on the cholesterol, urea and creatinine levels observed in individuals treated with this plant. $C$. arabica plant extract causes behavioral disorders in Wistar rats translated by disturbances in ACTH hormone levels. It seems that the extract of the Saharan $C$. arabica plant presents less risk and for this reason we recommend the use of bioactive molecules from plants in the biological control of insect pests.

\section{REFERENCES}

Abdelfattah, E., Rizk, M, N., Elregal, N., Ami, A. M., Sakr, M. (2019). Antidiabetic activity of callus extract of cleome droserifolia in rats. J. Mater. Environ. Sci, 10 (11), 1083-1097.

Ahmed, O.M., Abdel-Moneim, A., Abulyazid, E., Mahmoud, A.M. (2010). Antihyperglycemic, antihyperlipidemic and antioxidant effects and the probable mechanisms of action of Ruta graveolens infusion and rutin in nicotinamidestreptozotocin-induced diabetic rats. Diabetol Croat, 39(1), 15-35.

Baba-Aïssa, F. (2000). Encyclopédie des plantes utiles: Flore d'algerie et du maghreb, edition librairie moderne Rouiba (p368), Algeria.

Balandrin, M. F., Klocke, J.A., Wurtele, E., Bollinger, W.H. (1985). Natural plant chemicals: Sources of industrial and medicinal materials. Science, 228, 1154-60.

Bekhakheche, M., Manseur, A., Masna, F., Habbachi, S., Habbachi, W., Bairi, A., Tahraoui, A . (2014). Chronic Contamination in Rats by Reduced Risk Pesticides: Cases of Spirotetramat and Citrullus Colocynthis (Cucurbitaceae) Extracts. World Journal of Environmental Biosciences, 6(4), 1-6. 


\section{Current Trends in Natural Sciences}

Vol. 9, Issue 18, pp. 202-209, 2020

https://doi.org/10.47068/ctns.2020.v9i18.028

Current Trends in Natural Sciences (on-line)

ISSN: 2284-953X

Current Trends in Natural Sciences (CD-Rom)

ISSN: 2284-9521

ISSN-L: 2284-9521

ISSN-L: 2284-9521

Chacko, E. (2003). Culture and therapy: complementary strategies for the treatment of type-2 diabetes in an urban setting in Kerala. India. Soc Sci Med, 56, 1087-98.

Choudhury, S., Sinha, M.P. (2015). Effect of aqueous extract of Murraya koenigii on haematological, hormonal and lipid profile of Albino rats. J Coastal Life Med, 3, 901-05.

Crawley, J.N. (1999). Behavioral phenotyping of transgenic and knockout mice: experimental design and evaluation of general health, sensory functions, motor abilities, and specific behavioral tests. Brain. Res, 835 (1), 18-26.

Desneux, N., Decourtye, A., Delpuech, J.M. (2007). The sublethal effects of pesticides onbeneficial arthropods. Annu. Rev. Entomol, 52, 81-106.

Domschke, K., Zwanzger, P. (2008). GABAergic and endocannabinoid dysfunction in anxiety - future therapeutic targets? Curr. Pharm. Des, 14, 3508- 3517.

Doumandji-Mitiche, B., Doumandji, S. (1993). Essai de lutte biologique contre la Pyrale des Caroubes Ectomyelois ceratoniae Zeller (Lep., Pyralidae) par utilisation de Trichogramma embryophagum (Hym., Trichogrammafidae) à Ouargla [Biological control trial against the Carob Bean Moth Ectomyelois ceratoniae Zeller (Lep., Pyralidae) using Trichogramma embryophagum (Hym., Trichogrammafidae) in Ouargla]. Synthesis report of the workshop "Biological control in oases". Ed. CIHEM Montpellier, Mediterranean Options: Ser. A. Mediterranean Seminars. (p183). France.

Elizalde, N., Gil-Bea, F. J., Ramirez, M.J., Aisa, B, Lasheras, B, Del Rio, J., Tordera, R.M. (2008). Long-lasting behavioral effects and recognition memory deficit induced by chronic mild stress in mice: effect of antidepressant treatment. Psychopharmacology,199(1),1-14.

Elliott, B. M., Faraday, M. M., Phillips, J.M., Grunberg, N. E. (2004). Effects of nicotine on elevated plus maze and locomotor activity in male and female adolescent and adult rats. Pharmacol. Biochem. Behav, 77, 21-28.

Gaalen, M., Steckler, T. (2000). Behavioural analysis of four mouse strains in an anxiety test. Behavioural brain research, 115, 95-106.

Gubb, A.S. (1913). La flore saharienne: un aperçu photographique. Ed. Adolphe Jourdane, (p129). Algies, Algeria.

Helal, E.G.E., Abou Aouf, N., Abdallah, I.Z.A., Khattab, A.M. (2015). Hypoglycemic and Antioxidant Effects of Cleome Droserifolia (Samwah) in Alloxan-Induced Diabetic Rats. The Egyptian Journal of Hospital Medicine, $58,39-47$.

Isman, M.B. (2002). Problèmes et perspectives de commercialisation des insecticides d'origine botanique. In RegnaultRoger C., Philogène B.J. \& Vincen C., 2002. Biopesticidesd'origine végétale. Ed. Tec \& Doc,(p 301-311). Lavoisier, Paris.

Joel Enoch, B., Lenka Jessica, L., Luka Carrol, D. (2014). Effect of aqueous leaf extract of Murraya Koenigii on some biochemical and hematological indices of normal and alloxan-induced diabetic rats. Journal of Biological Sciences and Bioconservation, 6(2), 72-87.

Kamesh, V., Sumathi, T. (2012). Antihypercholesterolemic ef- fect of Bacopa monniera linn. on high cholesterol diet induced hypercholesterolemia in rats. Asian Pac J Trop Med, 949, 949-55.

Karl, T., Pabst, R., Von Horsten, S. (2003). Behavioral phenotyping of mice in pharmacological and toxicological research. Exper. Toxic. Pathol, 55, 69-83.

Kirby, LG., Lucki, I. (1997). Interaction between the forced swimming test and fluoxetine treatment on extracellular 5 hydroxytryptamine and 5- hydroxyindolacetic acid in the rat. J. Pharmacol. Exp. Ther, 282, 967-976.

Koïta, K., Neya, F.B., Nana, A.T., Sankara, P., Biosci, J.A. (2012). Activité antifongique d'extraits de plantes locales contre Puccinia arachidis Speg. Journal of Applied Biosciences, 57, 4142- 4150.

Kousteff, A. (2011). Etude de l'interaction entre stress chronique et polymorphisme de l'apolipoprotéine E dans les processus émotionnels et cognitifs chez la souris : implications dans la maladie d'Alzheimer ?. PhD thesis (Neurosciences). France: University of Strasbourg.

Ladhari, A., Laarif, A., Omezzine, F., Haouala, R. (2013). Effect of the extracts of the spiderflower, Cleome arabica, on feeding and survival of larvae of the cotton leafworm, Spodoptera littoralis. Journal of Insect Science, 13 (61).

Lister, R.G. (1987). The use of a plus-maze to measure anxiety in the mouse. Psychopharmacology, 92, 180-185.

Louat, F. (2013). Etude des effets liés à l'exposition aux insecticides chez un insecte modèle, Drosophila melanogaster. PhD thesis. France: University of Orléans.

Malwal, M., Sarin, R. (2011). Antimicrobial efficacy of Murraya koenigii (Linn.) Spreng. root extracts. Indian J Nat Prod Resour, 2(1), 48-51.

Möhler, H. (2006). GABA a receptors in central nervous system disease: anxiety, epilepsy, and insomnia. J. Recept. Sig. Trans. Res, 26, 731-740. 
N'guessan, K., Kadja, B., Zirihi, G.N., Traoré, D., Aké-Assi, L. (2009). Screening phytochimique de quelques plantes médicinales ivoiriennes utilisées en pays Krobou (Agboville, Côte-d 'ceIvoire). Sciences \& Nature, 6 (1), 1 R 15.

Oliver, C., Guillaume, V., Hery, F., Bourhim, N., Boiteau, K., Drieu, K . (1994). Effect of Ginkgo biloba extract on the hypothalamo-pituitary-adrenal axis and plasma catecholamine levels in stress. European Journal of Endocrinology, 130, 207.

Onaivi, E.S., Green, M.R., Martin, B.R. (1990). Pharmacological characterization of cannaboids in the elevated plus maze. J. Pharm. Exp. Therap, 253, 1002-1009.

Ozenda, P. (1991). Flore de Sahara. Mise à jour et augmentée. $3^{\text {ème }}$ Edition Dunod, CNRS . France, Paris.

Palanza, P. (2001). Animal models of anxiety and depression: how are females different? Neurosci. Biobehav. Rev, 25, 219-233.

Párraga, I., López-Torres, J., Andrés, F., Navarro, B., Del Campo, J.M., GarcíaReyes, M., Galdón, M.P, Lloret, Á., Precioso, J.C., Rabanales, J. (2011). Effect of plant sterols on the lipid profile of patients with hypercholesterolaemia. Randomised, experimental study. BMC Complement Altern Med. 11, 73.

Pellow, S., Chopin, P., File, S.E., Briley, M. (1985). Validation of open: closed arm entries in an elevated plus-maze as a measure of anxiety in the rat. J. Neurosc. Met, 14,149-167.

Petit-Demouliere, B., Chenu, F., Bourin, M. (2005). Forced swimming test in mice: a review of antidepressant activity. Psychopharmacology (Berl), 177(3), 245-55.

Porsolt, R., Le Pichon, M., Jalfre, M. (1977). Depression: a new animal model sensitive to antidepressant treatment. Nature, 266, 730-732.

Prut, L., Belzung, C. (2003). The open field as a paradigm to measure the effects of drugs on anxiety like behaviors: a review. Eur. J. Pharm, 463(1-3), 3- 33.

Quezel, P. (1978). Peuplement végétal des hautes montagnes de l'Afrique du nord. Encyclopédie biogéographique et écologique. Ed. Paul Lechevalier, (p 463). Paris, France.

Raff, H., Lee, J.J., Widmaier, E.P., Oaks, M.K., Engeland, W.C. (2004). Basal and adrenocorticotropinstimulated corticosterone in the neonatal rat exposed to hypoxia from birth: Modulation by chemical sympathectomy. Endocrinology, 145, 79- 86.

Rodgers, R. J, Dalvi, A. (1997). Anxiety, defence and the elevated plus-maze. Neurosci Biobehav Rev, 21(6), 801-810.

Samout, N., Bouzenna, H., Ettaya, A., Elfeki, A., Hfeiedh, N. (2015). Antihyercholestrolemic effect of Cleome arabica L on high cholesterol diet induced damage in rats. Excli journal, 14, 791-800.

Shapiro, K., Gong, W.C. (2002). Use of herbal products for diabetes by Latinos. J Am Pharm Assoc, 42, $278-9$.

Sharma, G.N., Dubey, S.K., Sharma, P., Sati, N. (2011). Medicinal values of bael (Aegle marmelos) (L.) Corr.: a review. Int J Curr Pharm Rev Res, 1(3), 12-22.

Tayaa, H. (2014). Impact de l'exposition gestationnelle au diazinon sur les rattes Wistar et sur le neuro - développement de leur progéniture. PhD thesis. Algeria: University of Annaba.

UNESCO. (1960). "Les plantes médicinales des régions arides. Recherches sur les zones arides". France, Paris.

Van Gaalen, M. M., Steckler, T. (2000). Behavioural analysis of four mouse strains in an anxiety test battery. Behav. Brain. Res, 115(1), 95-106. 